\title{
Download $\square$
}

https://doi.org/10.17721/2308-135 $\underline{\text { X }} . \underline{\text { 2019.46. }} \underline{\text { 64-73 }}$

UDC 359

Kovalska Lesia Vladimirovna, candidate of geographical sciences, associate professor, Vasyl Stefanyk Precarpathian National University, Ivano-Frankivsk, Ukraine

e-mail: gnatuk_L@ukr.net

Tkachenko Tetiana Ivanivna, candidate of geographical sciences, associate professor

Kyiv National University of Culture and Arts, Kyiv, Ukraine, e-mail: todria@ukr.net

Kovalska Angela Romanivna, Vasyl Stefanyk Precarpathian National University", Ivano-Frankivsk, Ukraine , e-mail: kovalska_angelika_romanivna @ukr.net 
Aim: The purpose of the article: To analyze the current state of the transport network development, the index of transport communication, the dynamics of the number of users of mobile communication services, on the example of Kyivstar Company in Ivano-Frankivsk region. Determine the role of transport and mobile networks in promoting and enhancing the development of tourism on the basis of multifunctionality, mutual permeability and complementarity of various elements of socio-economic systems.

Methods - the study of communicative and its role in the development of tourism on the example of the Ivano-Frankivsk region is based on the combination of methods of sectoral and territorial analysis.

In particular, a systematic approach is used for the study using comparative methods, statistical analysis, analytical analysis, etc.

This methodology includes an analysis of the conditions and factors of tourism development within the administrative unit of Ukraine based on statistical data of indicators (types of vehicles and connections, number of arrivals / departures of passengers, directions of tourist flows from / to Ivano-Frankivsk region, etc.).

Results - the article analyzes the impact of transport and mobile networks on the development of the tourism industry, for example, Ivano-Frankivsk region. The emphasis is placed on the index of transport communicativeness of the Ivano-Frankivsk region. The analysis of migration monitoring with the help of Kyivstar telecommunication operator was carried out, namely: citizens' migration in Ivano-Frankivsk, duration of their stay, geography of their arrivals. In comparison with the statistical indicators of the state of tourism development, external (country) and internal (oblast) donors of tourists are determined. The influence of communicativeness on the current state of the tourism industry is substantiated. 
Scientific novelty - for the first time, on the basis of sectoral-territorial analysis the state of development of the tourism industry through the prism of transport and mobile networks has been analyzed.

The results of the research may form the basis for writing course papers, theses, preparation of lecture-practical material, monitoring of the national tourism market.

Practical significance - materials of the publication, conclusions can be used during the educational process, preparing training for the national tourism industry, the practical activities of tour companies, to popularize the western region of Ukraine, on the example of Ivano-Frankivsk region on the external and internal tourist markets.

Key words: tourism, mobile and transport networks, Ivano-Frankivsk region, tourist flow, countries, regions of tourists' donors, index of communicativeness.

References:

1. Airport in Ivano-Frankivsk. Ivano-Frankivsk, 2017. URL: http://cfts.org.ua/news/2018/01/24/aj eroportu_ivano_frankovsk_utochnili_statistiku_passazhiropotoka_2017_45174 (

last accessed

:07.19.2018).

2. Ishchuk SI, Gladkyi O.V. Geography of industrial complexes URL: https://idruchniki.com/100 2080538444/rps/geografiya_promislovih_kompleksiv

(

last accessed

: 11.05.2018).

3. Kaluksky I.F., Kovalska L.V. Development of tourism in conditions of financial-economic instability and military-political conflict in Ukraine. Geography and Tourism. Kiev. Whip 33. 2016. S. $19-29$. 
4.Kalutsky I.F., Kovalska L.V., Vychivsky P.P. Tourism Development for the Disabled in Ukraine. Geography and Tourism. Kiev. Whip 35. 2017. S. 38-54.

5.Monitoring migration of citizens in the Ivano-Frankivsk region URL: http://www.dilovyi.com.ua /view.php?id=2734 accessed

: 10.10.2018).

6. Transport. URL statistics: (Date sent: Nov 19, 2013).

7.Tourism. URL statistics: http://www.if.gov.ua/news/27916 (last accessed: 19.11.2018).

8.Tourist streams. Statistics. URL: http://www.ifstat.gov.ua (last accessed: 07.19.2018). 